\title{
Construction of Legal Justice, Certainty, and Benefits in the Supreme Court Decision Number 46P/HUM/2018*
}

\author{
Asep Saepudin Jahar ${ }^{1}$, Raju Moh. Hazmi ${ }^{2}$, \\ Nurul Adhha ${ }^{3}$ \\ 1Syarif Hidayatullah State Islamic University, Jakarta Indonesia \\ ${ }^{2}$ Andalas University, Padang Indonesia \\ 3Institut Teknologi Sumatera, Lampung Indonesia \\ doi 10.15408/jch.v9i1.11583
}

\begin{abstract}
The philosophical discourse on legal justice, certainty, and benefits paradigm in the reality of Indonesian law reflect a strong indication of legal positivism in the Supreme Court decision. It causes a loss in the sense of justice and the hope for the community to meet legislative candidates with a clean track record and full of integrity. This study is normative-philosophical legal research applying the theory of justice developed by John Stuart Mill and John Rawls in highlighting the concept of legal justice, certainty, and benefits. The construction of justice in this decision applies the concept of justice as fairness as seen in the court consideration focusing on individual freedom (political rights to vote and to be elected). This is taken to protect the natural rights which are irreplaceable by any other rights. Meanwhile, the use of legal benefits and certainty is to reinforce the legal positivism paradigm. As the result, the study shows the three legal values (justice, certainty, and benefits) share equal positions in the country's legal framework.

Keywords: Legal Justice; Legal Certainty; Legal Benefits; Law; Supreme Court Decision
\end{abstract}

${ }^{*}$ Received: February 11, 2021, revised: February 18, 2021, accepted: March 18, 2021, Published: April 1, 2021.

${ }^{1}$ Asep Saepudin Jahar is a Professor of Sociology of Sharia and the Director of Graduate School, Syarif Hidayatullah State Islamic University, Jakarta Indonesia. ORCID: https://orcid.org/0000-00024957-5273

${ }^{2}$ Raju Moh. Hazmi is a Master's Student of Constitutional Law, the Faculty of Law, Andalas University, Padang Indonesia. ORCID: https://orcid.org/0000-0002-4049-9630

${ }^{3}$ Nurul Adhha is a lecturer in religion and Islamic ethics at Institut Teknologi Sumatera, Lampung Indonesia. ORCID: https://orcid.org/0000-0002-4943-6417 


\title{
Konstruksi Keadilan, Kepastian, dan Kemanfaatan Hukum dalam Putusan Mahkamah Agung Nomor 46P/HUM/2018
}

\begin{abstract}
Abstrak
Wacana filosofis paradigma keadilan, kepastian, dan kemanfaatan hukum dalam realitas hukum Indonesia mencerminkan indikasi kuat positivisme hukum dalam putusan Mahkamah Agung. Hal tersebut menyebabkan hilangnya rasa keadilan dan harapan masyarakat untuk bertemu calon legislatif dengan rekam jejak yang bersih dan penuh integritas. Penelitian ini merupakan penelitian hukum normative-filosofis yang menerapkan teori keadilan yang dikembangkan oleh John Stuart Mill dan John Rawls dalam menyoroti konsep keadilan, kepastian, dan kemanfaatan hukum. Konstruksi keadilan dalam putusan ini menggunakan konsep keadilan sebagai fairness yang terlihat dalam pertimbangan pengadilan yang menitikberatkan pada kebebasan individu (hak politik untuk memilih dan dipilih). Hal ini dijadikan pertimbangan untuk melindungi hak alami yang tidak dapat digantikan oleh hak lainnya. Sedangkan kemanfaatan dan kepastian hukum dijadikan pertimbangan untuk memperkuat paradigma positivisme hukum. Hasilnya, studi ini menunjukkan bahwa ketiga nilai hukum (keadilan, kepastian, dan manfaat) memiliki kedudukan yang sama dalam kerangka hukum negara.

Kata Kunci: Keadilan hukum, kepastian hukum, kemanfaatan hukum, hukum, putusan Mahkamah Agung.

\section{Постановлении № 46P/HUM/2018 Верховного суда}

Конструирование справедливости, определенности и преимущества закона в
\end{abstract}

\begin{abstract}
Аннотация
Постановление Верховного суда № 46P/HUM/2018 вызвало раскол в правовой парадигме в Индонезии. Философский дискурс между справедливостью, определенностью и преимуществами закона в реальности индонезийского законодательства отражает сильные симптомы правового позитивизма в постановлении Верховного суда. Это приводит к потере чувства справедливости и надежды сообщества на получение репутации чистых и порядочных кандидатов. Данное исследование является нормативно-философским правовым исследованием. Подход, основанный на теории справедливости Джона Стюарта Милля и Джона Ролза, был использован для понимания концепции справедливости, преимущества и правовой определенности в постановлении. Конструирование справедливости в постановлении использует концепцию справедливости как равенства (справедливость как честность), что можно увидеть из соображений судей, подчеркивающих индивидуальную свободу (политические права, право быть избранным и голосовать) как форму попытки отстоять либертарианские права или естественные права, которые не могут быть отменены свободой других людей. Между тем аспекты преимущества и определенности подчеркивают позитивную парадигму закона. В этом исследовании сделан вывод о том, что три юридические значимости (определенность, преимущество и справедливость) занимают не менее важное место в рамках правовой системы страны.
\end{abstract}

Ключевые Слова: Справедливость; определенность; преимущество закона; закон; постановление Верховного суда. 


\section{A. INTRODUCTION}

The Supreme Court Decision Number 46 P/HUM/2018 (PMA No. $46 / 2018$ ) is a decision resulting from a judicial review case on Article 4 paragraph (3), Article 11 paragraph (1) letter d, and Appendix B.3 in the Regulation of the General Elections Commission Number 20/2018 about the Elections for the People's Representative Council of Indonesia, the Regional Representative Council of Indonesia, and State Gazette Number 834/2018 according to the Law Number 7/2017 on General Elections. In its statement, the Supreme Court granted the petition requested by Jumanto (former corruption convicted prisoner) to conduct a Judicial Review on the Regulation of the General Elections Commission Number 20/2018:

Article 4 paragraph (3), Article 11 paragraph (1) letter d and Appendix B.3 have mentioned that the civil and political rights are new legal norms and are not regulated in the higher laws and regulations which in this case include Law Number 7/2017 on General Elections and the provisions of Article 4 paragraph (3), Article 11 paragraph (1) letter d, and Appendix B.3 in the Regulation of the General Elections Commission Number 20/2018, provided that the phrase former corruption convicted prisoner has contradicted the Law Number 7/2017 on General Elections in conjunction with the Law Number 12/2011 on the Establishment of Legislation.

The request to remove this phrase would allow candidates to be qualified for legislative election even though they are or have been suspects in cases of alleged corruption. This request has triggered public criticism of the Supreme Court decision. (Riewanto, Opini Media Indonesia, September 17, 2018). According to the public, the Supreme Court decision ruins the noble desire of the General Elections Commission and Indonesian citizens to build integrous and democratic elections. In addition, it also obstructs the public aspirations to vote for candidates who are clean and have a great track record. (Shaleh dan Hunafa, 2018: p. 1069-1086.)

Suffice to say the Supreme Court Decision deliberately approves the qualifications of parliament candidates who have committed acts of corruption. This decision also reflects the insensitivity of the Supreme Court in responding to public aspirations. As a democratic country, Indonesia strives to run and apply the best standards to only recruit legislative candidates with integrity, those who act with honesty, honour, and truthfulness. Sadly, the decision opposes the public conscience which designates the corrupt officials as public enemies. In the minds of the citizens, they do not deserve to become the People's Representative Council members. In another case, the decision also leads to a philosophical debate. It implies that the legal system in Indonesia 
does not reflect a progressive legal paradigm and indicates that Indonesian law favours procedural rules rather than a sense of justice in the lives of the citizens and the benefits of democracy. (Farisa, Kompas.com: September 15, 2008).

Further, the decision has divided the legal paradigm in Indonesia. The philosophical struggle on legal justice, certainty, and benefits has again encouraged paradigmatic discussion and discourse on the reality of Indonesian law (Prasetyo and Barkatullah, 2012: p. 196). On the one hand, the legal positivism point of view in the Supreme Court Decision has eliminated the sense of justice and the hope for the community to meet legislative candidates with a clean track record and full of integrity. The legal positivism scholars expect the discharge of meta-juridical elements from the legal ontology. Every legal norm must exist in its objective nature as positive norms and be specified in term of a concrete agreement between the citizens and their representatives (Atmadja, 2013: p. 41). In this understanding about the shift in the concept of law, the law is no longer constructed as meta-ethics in nature, but ius which has experienced positivism as lex. Consequently, the essential objective of law to produce legal certainty to create order in morality, justice, politics, culture, and society has disappeared from the court consideration (Friedrich, 2004: p. 135).

In making a decision, the Supreme Court does not only depend on the principle of legal certainty for the petitioner but also the legal justice and benefits that must be reflected in its considerations (James, 2012: p. 241-324). The law serves to bring justice as a reality in regulating human relations. It must be capable of building reciprocal harmonization in the context of its interests (Rasjidi, 1993: p. 184). In addition, it must be placed according to its benefits for the citizens as it is a crystallization of the social heart that embodies the spirit or soul of a nation (volkgeist). The Law and the citizens are two sides of a coin. The good law is the law that holds moral and political legitimacy in society and serves their aspirations, conscience, hopes, needs, and culture (Marwan, 2010: 18). This is in line with Ronald Dworkin's opinion saying that the law is not a pile of orders. It is a sense of morality which rationally and philosophically sculpted and eventually leads to the reconstruction of ideal legal decisions (Leiter, 2011: p. 865.-893). The Supreme Court Decision Number $46 / 2018$ suggests multiple interpretations on the objectives of law that must be upheld. For this reason, this study aims at illustrating the philosophical dialectics regarding the legal justice, certainty, and benefits in the Supreme Court Decision. The study also analyzes the way the representation of justice is based on the Supreme Court considerations. 


\section{Literature Review}

Renata Rizqi (2019) has conducted a study entitled "The Implications of the Supreme Court Decision Number 46P/HUM/2018 on Nominations for Former Corruption Convicted Prisoner (Legal Discovery and Maqâșid Sharia Perspective)". This study is a literary and normative legal research that applies descriptive analysis to examine the research data. In the study, Rizqi uses the theory of teleological/sociological interpretation and the theory of maqâșid sharia. The theory of teleological/sociological interpretation which is used to analyze the Supreme Court Decision Number 46P/HUM/2018 shows the implication of the Law Number 7/2017 on General Elections; precisely article 240 paragraph (1) letter $\mathrm{g}$ is no longer relevant to apply in Indonesia given the fact that the Indonesian citizens oppose former corruption convicted prisoners to run for legislative positions and the out-of-control corruption cases committed by the legislative members take place. The public fully agrees with Article 4 paragraph (3) in the Regulations of the General Elections Commission which prohibits the former corruption convicted prisoners from becoming legislative candidates. In the meantime, the theory of maqâsid sharia theory suggests the negative implications they cause are more than the positive ones. Consequently, the decision is not in line with the objectives of maqâșid sharia, for the benefit of the people (public interest).

\section{B. METHODS}

This study is normative-philosophical legal research (Christiani, 2016: p. 201-207). The research applies the theory of justice developed by John Stuart Mill and John Rawls to analyze the concept of legal justice, certainty and benefits in the Supreme Court Decision Number 46 P/HUM/2018. With qualitative methods, it conducts an in-depth understanding of the decision aspect (Arief Sidharta, 2007: p. 2). In addition, it uses an in-depth analysis with a constructivism approach to highlight the critical-analytical decisions in terms of their characteristics (Poerwandari, 2007: p. 22-23).

\section{RESULTS AND DISCUSSION}

\section{The Essence of Court Decisions}

Referring to Article 24A paragraph (1) of the 1945 Constitution, the Supreme Court has the right to conduct a judicial review on all regulations and decisions that may contradict the applicable laws. If the Court finds that 
regulation or decision contradicts the applicable laws, such regulation or decision would be considered inapplicable or invalid, and orders any institutions that have issued it to revoke it. This matter is regulated under Law Number 14/1985 which is amended by Law Number 3/2009 on the Supreme Court. Generally, the court is a means of seeking legal justice, certainty, and benefits to adjudicate legal disputes between parties. Every court consideration depends on the three principles in deciding cases. The existence of justice, certainty, and benefits is seen from the argumentation and consideration of the decision (Fallon Jr., 1997: p. 1-56). In solving the cases, the court makes a decision that is independent, impartial, and free from the intervention of any parties. The Court is only bound by events, relevant facts, and legal principles as the juridical basis (Wantu, 2007: p. 388-398). This causes the implementation of judicial power to always seemingly refer to the accuracy of the court in exploring, following, and understanding the legal values and the sense of justice that have lived in society.

The Court can make a good decision adhering to the law (system Denken) and, at the same time, considers its conscience to pay a great deal of attention to the legal justice and benefits when the decision has been made (problem Denken) (Pound, 1944: p. 185-222). The Court decision which is based on the law of sich (thing-in-itself) and does not recognize its conscience will fail the Court to present legal justice and benefits and be unable to solve a case within the justice and law enforcement framework (Respationo, et al., 2013: p. 101 -107). For this reason, considering the legal justice, certainty, and benefits is a power to solve any legal issues (Mertokusumo, 2014: p. 43).

Good law enforcement and implementation will lead to proportional considerations on the three values; justice, certainty, and benefits. This is in line with Gustav Radbruch's statement in Leawoods (2000) saying the law as the complex rules of coexistence must be present to give legal benefits, justice, and certainty (Leawoods, 2000: p. 489-519). The nature of the law is a willingness to bring justice and treat everyone equally considering it is a rule to follow and apply to all levels of society to ensure legal certainty.

Radbruch mentions the law has an important meaning to create legal ideals. Such ideals are interpreted as something that precedes (Radbruch, 2006: p. 13-15). According to Rhiti, the law is also transcendental. Therefore, legal ideals are hypothetical concept. The mind has subjective existence, and this does not prevent it from making objective judgments (Rhiti, 2012). This means a positive law is the tangible manifestation (sein immanent) of ideals as transcendental-logical laws. This transcendental-logical nature is traceable 
through three aspects; legal justice which explains the equal rights before the law, the legal benefits which lead to the objectives of justice as the manifestation of goodness in human life that determines the content of the law, and the legal certainty which means ensuring the law that contains justice and norms promoting goodness must be obeyed (Tanya, et al., 2007: p. 151).

Accordingly, the three legal values (justice, certainty, and benefits) have an equally important part in the country's legal framework. If the three are conflicted, the Court plays a role to equally apply them. Its role in considering the three elements is very essential. It cannot depend or lean on only one value and ignore the other two. In other words, the three needs to build a strong relationship and compromise even though in practice proportionally compromising is hard to follow (Mertokusumo, 2005: p. 161).

\section{Justice Is the Greatest Joy}

Utilitarian scholars see justice as the greatest good. John Stuart Mill, for example, mentions that the scholars aim the paradigm of justice towards the greatest benefit or principle of happiness (Lindebaum, et al., 2017: p. 813-822). An action is considered right if it brings and adds up to happiness (Lebacqz, 1986: 14). The standard of justice is based on its uses and benefits. The justice itself comes from human instincts to reject and fix some damage. For this reason, a sense of justice will naturally exist to prevent damage or suffering. (Rahardjo, 2000: p. 271).

According to Mill, happiness is measurable by two things, pleasure and painlessness. His statement leads to two crucial assumptions underlying the dialectic of justice according to the utilitarian perspective, saying that the life purpose is happiness and the truth of an action is determined by its contribution to happiness. Bentham also confirms that happiness is terminologically correlated with pleasure and the absence of pain (Bentham, 1781: p. 11-12). Mill argues that pleasure and pain are different. One example of pleasure is an intellectual pleasure which is more useful than physical pleasures according to the majority of people. It is intrinsically more distinguished and more precious. In this context, the meaning of happiness here divides the utilitarian into two groups. The first group considers the essential happiness exists in pleasure and pain relief (hedonistic utilitarianism), while the other one suggests that happiness is related to truth and beauty (Ideal Utilitarianism) (Lebacqz, 1986: p. 15). Regarding the opinion of the second group, the truth of action is largely determined by its contribution to happiness. 
Referring to the above description, Bentham, on the one hand, finally concludes that every action is precisely measured and time-consuming. On the other hand, Mill simplifies his conclusion stating that individual action is justified based on its benefit to all parties. Therefore, an action is considered right or wrong depending on the beneficial contribution experienced by all parties. The relationship between justice and happiness does not happen independently, but it relies on each of their respective benefits. To that end, Mill says justice is a certain moral requirement that collectively stands higher than social benefit (Nodelman, et al., 1995).

Justice becomes a more dominant requirement than other moral requirements. Mill even points out that justice extremely depends on benefits as the conflicts in the general rules of justice can only be resolved by referring to the principle of benefits. Mill adds that justice is a set of certain moral rules that define the essence of human benefits more closely than other moral rules. In this sense, the idea of justice is a right given to an individual user to testify a more binding obligation (Fahmi, 2016: p. 167-186). According to Mill, Justice is understandable through three stages. The first stage is exploring and measuring the forms of injustice and investigating its general nature. The second stage is investigating the causes for the arising of strong feelings about justice and examining if these feelings are based on benefits. Examining several controversial cases to show the urge for justice will not be able to answer the controversy because the aspect of benefits can only be measured based on calculations (Lebacqz, 1986: p. 18).

Mill further says sentiment for the sense of justice stems from the animal desire to reject or respond to pain for the damage to itself and others (Mill, 1961). When a person is faced with the subordination of social sympathy, the desire to respond to it can change. Those who break the rules should be punished. At this level, this desire will turn into a moral feeling. Behind justice lies security interest. Such a relationship is the most vital interest among the existing interests (Anderson, 1991: p. 4-26. The rules of justice are supported by benefits to maintain the sense of security, meaning when one asks why society should defend his/her rights, the answer lies in the common interest for the sense of security itself.

In short, the benefit is the basis to seek justice as the benefit itself can measure justice. An action is considered justice or injustice depends on the principle of benefit. The utilitarian paradigm suggests that to define right or wrong in a rule or action, a direct consequence is taken or considered to some extent. If the rule or action has a good consequence, then it is considered right 
and fair. In contrast, if it results in a bad consequence, it is then regarded as wrong and unfair (Ujan, 2001: p. 21).

\section{Justice Is Equality}

The utilitarianism paradigm has a weakness in seeing justice. In its perspective, justice seems to be confusing (Wolf, 1977: p. 11). This is seen from the lack of respect for individual rights. Such weakness encourages Rawls (1971) to propose an alternative theory to deconstruct the utilitarianism perspective. His theory seeks to completely accommodate individuals without negating their welfare or rights for the benefit of others (Lebacqz, 1986: p. 49). His position as a liberal egalitarian of social justice has given birth to the idea of justice that stands on two main concepts, the original position in the natural state such as the classical theory (original position) and the veil of ignorance (J.Mandle, 2002: p. 265-268, Stein, et al., 2005: p. 147-172). The result of his theory is justice as fairness (Efendy, 2014: p. 77-78). The principle of justice as fairness is proven from his quote stating that: First, each person is entitled to have an equal right at the most extensive scheme of equal fundamental freedom which is compatible and similar to the freedom of others, and second, social and economic inequalities are to be arranged so that they are both (a) reasonably expected to be at everyone's advantage and (b) bound to positions and offices which are open to all (Rawls, 1971: p. 53).

Rawls' first idea is similar to the rules of the common law initiated by Immanuel Kant. According to Kant, individual freedom is postulated from the general enforceability of categorical imperative deriving from moral principles based on the unification of one's freedom and another's (Meuwissen, 2007: p. 85-87). Therefore, this first principle is regarded as a principle associated with the freedom of citizens to manifest political freedom (the right to vote and to be elected for public office). This includes freedom of expression and association, freedom of belief, freedom of thought, freedom to defend property rights, and freedom from arbitrary arrest as stipulated by the rule of law. To this end, the formula for the first principle is equality as every individual in a just society has the same basic rights.

Rawls' second principle represents the basic to distribute income, wealth, and organizational design using different means of authority, responsibility, or chain of command. This indicates the principle of the distribution of wealth and income does not always mean the same amount but must be based on the benefits for everyone. At the same time, the position of 
authority and chain of command must be accessible to everyone. These two principles are in a lexical order, which means they represent levels of priority. Here, the first principle is a priority that must be met before the second principle. The levels of priority reinforce the principle of the priority of liberty (freedom) which exists for the sake of the freedom itself (freedom over freedom). Meanwhile, the second priority describes the priority of justice for efficiency and welfare. In a democratic society, each individual is assumed to have freedom and responsibility for his/her self in a democratic association. Individual freedom can only be restricted by other freedoms. Rawls mentions that in the perspective of justice as fairness, freedom can be restricted for a condition where such restriction can lead to inequality in political freedom. However, this inequality may happen if ensuring the freedom of disadvantaged groups is considered necessary (Kelsen, 1992: p. 105). Justice can only be seen in a society, not individually. In this context, Rawls agrees with Hans Kelsen's opinion that justice is happiness that cannot be found as an individual. Therefore, it must be sought in society (Ducey, 1959: p. 54). Suffice to say that justice is said to be social happiness.

The concept of justice as fairness offers a dichotomous boundary to the utilitarian paradigm. The principle of justice cannot be found by evaluating the benefits of an action or the tendency of the action to bring benefits, but making a rational choice in fair conditions (repositioning conditions can create rationality for justice) (Kelsen, 1992: p. 16). Mill's utilitarian approach allows for the exclusion of individual rights against the demands of the greatest good of others. In the meantime, the principle designed by Rawls protects the disadvantaged from society. One's freedom or welfare cannot be changed for the welfare of others. The basic freedoms must be equally distributed and cannot be given up for economic gain. The inequality in social status, privilege, and power may be taken as long as they can lead the less fortunate parties to a better condition than the previous one (Lebacqz, 1986: p. 61). Referring to two aforementioned concepts of justice, the question is, how is the justice in the Supreme Court Decision No. 46 P/HUM/2018 constructed?

\section{The Representation of Justice in the Supreme Court Decision No. 46 P/HUM/2018}

Based on the authors' analysis on the Supreme Court Decision No. 46 $\mathrm{P} / \mathrm{HUM} / 2018$, the object of the dispute is the Judicial Review on the prohibition of former corruption convicted prisoners from becoming legislative candidates (the People's Representative Council of Indonesia and the Regional 
Representative Council of Indonesia) which is stipulated on Article 4 paragraph (3), Article 11 paragraph (1) letter d in the Regulation of General Elections Commission Number 20/2018. The construction of the regulation is unequal, discriminatory, unfair, and partial. This is seen from the facts in the trial stating:

a. The constitutional right to rerun for election (candidates for the Regional Representative Council of Indonesia in Probolinggo Regency, in this case) is hindered by the norms mentioned in Article 4 paragraph (3) and Article 11 paragraph (1) in the Regulation of the General Elections Commission No. 20/2018 which prohibits former corruption convicted prisoners from participating in the election of legislative candidates and political party screening. After some analysis, Law no. 7/2017 does not regulate the norms prohibiting former corruption convicted prisoners from rerunning for election.

b. The norm enforcement on the prohibition has obstructed a person's right to participate in general elections, even though a norm cannot be enforced without a court decision that has permanent legal force. This has violated the validity of the principle of legal certainty.

c. The norm mentioned in the Regulation of the General Elections Commission No. 20/2018 also restricts a person's constitutional rights to promote himself/herself in the life of the nation and state. This provision has punished a person without a valid judicial process.

d. Essentially, the provision stated in Article 4 paragraph (3) and Article 11 paragraph (1) in the Regulation of the General Elections Commission No. 20/2018 has violated the principle of the constitutionality rights of citizens to be elected, the legal uncertainty in the implementation of rights restrictions, and the restrictions on collective rights to promote the life of the nation and state as reinforced in the 1945 Constitution of the Republic of Indonesia.

In considering the verdict in this case, the judicial panel argues that the right to vote and to be elected is a basic right protected by the constitution, precisely on Article 28 of the 1945 Constitution dated on December 16, 1966. It has been ratified by Law No. 12/2005 concerning the ratification of the International Covenant on Civil and Political Rights (ICCPR). Further, Article 43 paragraph (1) and Article 73 of the Law no. 39/1999 on Human Rights concludes that the restrictions on the right to vote and to be elected can only be made through legal materials or based on a court decision that has permanent legal force according to the provision mentioned on Article 18 Paragraph (1) 
letter d of the Law No. 31/1999 about the Eradication of Corruption in conjunction with Article 35 paragraph (1) of the Criminal Code which regulates that the revocation of political rights can only be carried out through an in crach van gewisjde decision.

In addition, the Regulation of the General Elections Commission No. 20/2018 contradicts Article 240 paragraph (1) letter g of the Law on General Elections because no norm or regulation prohibits former corruption convicted prisoners from running for election as stated in the Regulation No. 20/2018. Thus, the prohibition means restricting a person's political rights to run for legislative election, which principally must be restricted under the power of law. In addition, the legal material in Regulation No. 20/2018 also contradicts Article 12 letter d of Law No. 12/2012 on the Formation of Legislative Regulations considering the regulations under the law consist of legal materials to carry out the law properly. In this case, the General Elections Commission has made provisions that are not instructed by the higher laws and regulations.

These norms are new legal norms that are not regulated in the higher legislation, which is Law no. 7/2017 on Elections. In this regard, Article 4 paragraph (3), Article 11 paragraph (1) letter d, and Appendix B.3 which regulates the political rights of citizens are new legal norms that are not regulated in the higher laws and regulations. The Law Number 7/2017 on General Elections and the provisions mentioned in Article 4 paragraph (3), Article 11 paragraph (1) letter d, and Appendix B.3 in the Regulation of the General Elections Commission Number 20/2018 which mention the phrase former corruption convicted prisoners must be declared contrary to the Law Number 7/2017 on General Elections in conjunction with the Law Number 12/2011 on the Formation of Laws and Regulations.

In connection with the above description, the justice in the Court decision embodies the concept of justice as fairness. This is seen from the consideration that the restriction of a person's political rights (the right to vote and to be elected) can only be made through legislation. The justice that is constructed as fairness seeks to fully accommodate the natural rights of individuals without risking and negating their welfare or rights for the good of others. Even though morality is universal, the house of parliaments should be occupied by legislative candidates who have integrity and a clean track record, the principles related to the freedom of citizens as the manifestation of political freedom (the right to vote and to be elected for public office) are absolute and equal rights (Meuwissen, 2007: 85-87). 
Further, the decision implicitly confirms that justice cannot be found by evaluating the benefits of an action or the tendency of the action to bring benefits, but making a rational choice in fair conditions (repositioning conditions can create rationality for justice). This is seen from the lack of court consideration in illustrating a more futuristic benefit to close the gap in the renomination of former corruption convicted prisoners to build a clean parliament for the political future of state administration. This is very essential because corruption has a tendency to repeat itself and the recidivist phenomenon in corruption cases often occurs. In 2017, the Corruption Eradication Commission recorded 20 (twenty) out of 102 (one hundred and two) corruption cases involving central and regional government bureaucratic officials. They were members of the People's Representative Council of Indonesia and the Regional Representative Council of Indonesia. For this reason, the Court must refer to this case to achieve greater benefits in the future.

Sadly, the considerations in the decision focus more on the lexical order (levels of priority rights). This is seen from the legal reasoning which states that the freedom of former corruption convicted prisoners to run for office can only be restricted as such restriction can result in inequality in political freedom. The inequality may happen if ensuring the freedom of disadvantaged groups is considered necessary. For this reason, one's freedom or welfare is unchangeable with the freedom or welfare of others. The basic freedoms must be equally distributed. If this verdict is set on the concept of justice (the greatest happiness and equality), it is essentially aimed at the concept of justice as fairness which guarantees the individual political freedom as part of the absolute natural rights without some distortion by the interests and welfare of others.

\section{Construction of the Legal Certainty and Benefits in the Supreme Court Decision No. 46 P/HUM/2018}

The legal certainty includes two definitions of law, ius which gives birth to the idea of morality and justice, and lex expands which is the notion of law as legal positive rights and obligations. The portrait of legal certainty in the Supreme Court Decision No. 46 P/HUKM/2018 uses the legal concept as lex. This is reflected in the arguments which refer to the provisions of the positive law an sich. Referring to the norm construction of Article 240 paragraph (1) letter $\mathrm{g}$ in the Law on General Elections, candidates for the People's Representative Council of Indonesia and the Regional Representative Council of Indonesia are Indonesian citizens who must meet the requirement of never being sentenced to prison, based on the Court decision that has permanent legal 
force, for committing a crime punishable with 5 (five) or more year imprisonment unless they openly and honestly inform the public that they are former corruption convicted prisoners. In this way, no norms or rules prohibit them from running for election as stated in the Regulation of the General Elections Commission Number 20/2018.

Consistency in the enforcement of positive legal norms (the Law on General Elections and the Law on the Establishment of Legislation) that are confronted with the Regulation of the General Elections Commission Number 20/2018 (regardless of the fair or unfair dimension) has shown that the Court relies on the legal certainty as lex in deciding cases because the contents of the Law on General Elections and the Law on the Establishment of Legislation become the basis to formulate a touchstone which is the driving force for the legal certainty. The legal certainty here is written under the following principles; right on target, finality, and legal objectives. The law is used as a means of protecting individuals from the arbitrariness of the authorities. At this stage, it is very logical that the legal materials in the Law on General Elections and the Law on the Establishment of Legislation become a means of protection to restrict a person's political rights referring to the concept of legal certainty. In the meantime, the legal certainty itself is defined by certain characteristics including 1) the law is positive law (legislation) and 2) the law and regulation must be based on reality (legal certainty requires the enforcement of a positive law) (Rhiti, 2013: 3).

The positivism paradigm has isolated the law from cultural, moral, and social dimensions (Kelsen, 2008: 68) which ultimately reaches the stage where the law as a regulatory system is seen as a mere technical tool for social control [3] Vega, 2018: p. 1-24). By including every legal issue into the legal framework, all legal issues are likely to be resolved under the maximum standards of legal certainty. If the need for legal certainty is met, the sense of justice and benefits will also be fulfilled. The construction of legal positivism which is centered centered on state law is very beneficial and makes it easier for the political elites, power holders, and capitalists to uphold and solve any legal issues. This is because the construction can deal with all kinds of legal issues that exist in a plural society (Eiter, 2001: p. 278-301). In this context, prohibiting former corruption convicted prisoners from running for election as legislative members is necessary considering the practices of corruption, collusion, and nepotism in Indonesia have undermined and damaged the life of nation and state.

Therefore, the judicial panel is supposed to be able to comprehend the "universal morality" of anti-corruption reflected in the Regulation of the 
General Elections Commission Number 20/2018 as an instrument to take early prevention and anticipatory measure to avoid corrupt behaviors from entering. The values that have been upheld by society to fight against corruption (universal morality) are the manifestation of the natural ideals to eradicate corruption in this country. To that end, the law must reflect such morality.

The Court decision must understand the natural ideals in the sense of community justice and not place temporary interests as broader goals and benefits. Law enforcement does not work in a social vacuum. It is always consistent with the development of society. The application of the law (decision) must regard considerations of how the law should reinforce social benefits (Malby, 2017: 521-532). The decision made by the Court does not arise from arbitrariness. It is based on principles, social wisdom, and morality. Here, the Court must consider the social dynamics reflected in morality in making the decision (Hart, 1994: 203-204). As the law is ius, it is a transcendental idea of morals and justice. However, it is intolerable for corruption recidivists to reenter and hold power in state institutions both in central and regional government. The state cannot take more risk from this right. Therefore, precautionary measures should be taken from the beginning.

Legal certainty is not a historical thing and free of value. It is the result of the construction and the totality of the human constellation. To this end, it is inseparable from psychological and political processes. It is nothing more than an undeniable reification so that it seems concrete. Intellectually, the battle of the paradigm between those who survive the purity or scripturalistic interpretation of the legal text and those who stick to the hermeneuticphilosophical interpretation takes place. The law with new texts is a beginning that needs continual interpretation efforts (Silkenat, et al., 2014). The nature of law is normative as it departs from norms, but the norms of a rule cannot immediately be applied. An effort to seek reasoning as a basis for legal considerations must be made. A quality decision cannot be understood textually, but it takes interpretation and contemplation to find out the values in it. The law seeks to have a dialogue with the context and involves the judicial Court conscience. At this stage, the norm of prohibiting former corruption convicted prisoners from running for re-election in parliament is metateleological.

In connection with the above illustration, the benefit of the finality of the decision should lead to justice in promoting the greater good of human life. The legal benefit is also contested as an element to bring benefits for the society in the way many individuals in the society become happy (Darmodiharjo and 
Shidarta, 2004: 117). Sadly, this decision is missing the consideration to gain future social benefits as it does not consider public rights. The public has the right to get the political representation that is free from corruption recidivists. In addition, by formulating the Regulation of the General Elections Commission, efforts to prevent corruption will be handled by the state administration by giving some restrictions to the convicted. The presence of the regulation is also significantly beneficial, especially with the existence of warning rules to prevent legislative members from involving in corruption, collusion, and nepotism practices in the future. Their actions will greatly affect their political career.

\section{CONCLUSIONS}

Referring to the analysis on the Supreme Court Decision No. 46 $\mathrm{P} / \mathrm{HUM} / 2018$, the construction of justice tends to adhere to the concept of justice as fairness developed by John Rawls. This is seen from the Court consideration which focuses more on individual freedom (political rights to vote and to be elected) as a form of natural rights-based libertarianism that cannot be restricted by other freedoms. Further, the legal benefits and certainty mostly reflect the Legal positivism paradigm. This is proven by the following two considerations: first, consideration of common interests (the greatest benefit) in the decision which becomes a touchstone to see the implications of the prohibition norms for former corrupt convicted prisoners from running for future election is not included. This means the legal certainty in this decision only defines the law as lex and negates the ontological basis of the law as an ius which fully considers the notion of morality and justice, without attempting to reveal what is behind the text (meta-teleological aspects), the Regulations of the General Elections Commission Number 20/2018 in this case. Here, the argumentation that only prioritizes and relies on the logical system is opposed by the Law on General Elections and the Law on the Establishment of Legislation in rejecting and prohibiting former corruption convicted prisoners from becoming legislative candidates or members. Such argumentation is not contemplated and aimed at the goals and legislative candidate ratio. Consequently, the constellation of the following three aspects; legal justice, certainty, and benefits in the Supreme Court Decision No. 46 P/HUM/2018 philosophically ends up in a strong legalism symptom in the reality of the Indonesian justice system. 


\section{REFERENCES:}

\section{Books}

Golovatyi, S. (ed.) (1996). Constitutions of the new states of Europe and Asia. Kyiv: Ukrainian Legal Foundation; Publishing house "Law".

Ujan, A. A. (2001). Keadilan dan Demokrasi: Telaah Filsafat Politik John Rawls. Yogyakarta: Penerbit Kanisius.

Marwan, A. (2010). Teori Hukum Kontemporer Suatu Pengantar Posmoderenisme Hukum. Yogyakarta: Rangkang Education.

Bentham, J. (1781). An introduction to the principles of morals and legislation. McMaster University Archive for the History of Economic Thought.

Tanya, B. L., Simanjuntak, Y. N., \& Hage, M. Y. (2007). Teori Hukum. Surabaya: CV Kita.

Friedrich, C. J. (ed.) (2004). Filsafat hukum perspektif historis. Bandung: Nuansa dan Nusamedia.

Darmodiharjo, D. (1995). Pokok-pokok filsafat hukum: apa dan bagaimana filsafat hukum Indonesia. Gramedia Pustaka Utama.

Ducey, M. H. (1959). The legal positivism of Hans Kelsen. Thesis of Graduate School of Loyola University.

Hart, H. L. A., Hart, H. L. A., \& Green, L. (2012). The concept of law. oxford university press.

Hans Kelsen. (1992). Introduction to The Problems of Legal Theory, translated by Bonnie Litschewski Paulson and Stanley L. Paulson, Oxford: Clarendon Press.

(ed.) 2008. Teori Hukum Murni Dasar-Dasar Ilmu Hukum Normatif, Bandung:Nusa Media.

Hyronimus Rhiti, (2012). Filsafat Hukum: Dari Klasik Sampai Postmodernisme, Yogyakarta: Penerbit UAJY.

Atmadja, I. D. G., \& Gede, D. (2013). Filsafat Hukum: Dimensi Tematis dan Historis. Malang: Setara Pers.

Rawls, J. (2009). A theory of justice. Harvard university press.

Lebacqz, K. (1986). Six theories of justice: Perspectives from philosophical and theological ethics. Augsburg Books.

Rasjidi, L., \& Putra, W. (2003). Hukum Sebagai Suatu Sistem. Bandung: Mandar Maju. 
Effendy, M. (2018). Teori Hukum dari perspektif kebijakan, perbandingan dan harmonisasi hukum pidana. Jakarta: Referensi.

Meuwissen, (ed.) (2007). Tentang Pengembanan Hukum, Ilmu Hukum, Teori Hukum, Filsafat Hukum, diterjemahkan oleh B. Arief Shidarta, Bandung: Refika Aditama.

Nodelman, U., Allen, C., \& Perry, J. (1995). Stanford encyclopedia of philosophy.

Simon, R. L. (1978). Understanding Rawls: A Reconstruction and Critique of A Theory of Justice. Princenton: Princeton University Press.

Rahardjo, S. (2000). Ilmu hukum. Citra Aditya Bakti.

Silkenat, J. R., Hickey, J. E., \& Barenboim, P. (Eds.). (2014). The legal doctrines of the rule of law and the legal state (Rechtsstaat) (Vol. 38). Heidelberg: Springer.

Mertokusumo, S. (2005). Mengenal Hukum Sebagai Suatu Pengantar. Liberty. Yogyakarta.

Mertokusumo, S. (2014). Penemuan Hukum Sebuah Pengantar, Edisi revisi. Yogyakarta. Cahya Atma Pustaka.

Prasetyo, T., \& Barkatullah, A. H. (2012). Filsafat, Teori, dan Ilmu Hukum Pemikiran Menuju Masyarakat yang Berkeadilan dan Bermartabat. Raha Grafindo Persada, Jakarta.

Rizqi, Renata (2019). Implikasi Putusan Mahkamah Agung Nomor 46P/HUM/2018 terhadap Pencalonan Mantan Korupsi (Perspektif Penemuan Hukum dan Maqâșid Syariah). Masters thesis, UIN Sunan Kalijaga.

\section{Journal Articles}

Cabral, James E., et al. "Using technology to enhance access to justice." Harv. JL $\mathcal{E}$ Tech. Volume 26. Number 1 (2012), 241.

Hyronimus Rhiti, "Kepastian Hukum dari Perspektif Fenomenologi dan Posmodernisme", Makalah Pleno Konferensi Ke-III Asosiasi Filsafat Hukum Indonesia, Surabaya, Tgl 27-28 Agustus 2013, Universitas Airlangga.

Leawoods, Heather. "Gustav Radbruch: An extraordinary legal philosopher." Wash. UJL \& Pol'y. Volume 2 (2000), 489.

Leiter, Brian. "In Praise of Realism (and against Nonsense Jurisprudence." Geo. LJ. Number100 (2011), 865. 
Leiter, Brian. "Legal realism and legal positivism reconsidered." Ethics. Volume 111. Number 2 (2001), 278-301.

Muhammad Saleh dan Dimas Firdausy Hunafa, "Pemilu Berintegritas: Menggagas Pencabutan Hak Politik Bagi Narapidana Tindak Pidana Korupsi yang Dipilih Melalui Pilihan Umum", Jurnal Universitas Negeri Semarang, Volume 4. Number 3 (2018), 1069-1086.

Pound, Roscoe. "Law and Morals--Jurisprudence and Ethics." NCL Rev. 23 (1944), 185-222.

Wantu, Fence M. "Antinomi Dalam Penegakan Hukum Oleh Hakim." Mimbar Hukum-Fakultas Hukum Universitas Gadjah Mada. Volume 19. Number 3 (2007), 395.

\section{Journal Articles with DOI}

Christiani, Theresia Anita. "Normative and Empirical Research Methods: Their Usefulness and Relevance in the Study of Law as an Object." ProcediaSocial and Behavioral Sciences. 219 (2016): 201-207. https://doi.org/10.1016/j.sbspro.2016.05.006

Fahmi, Khairul. "Menelusuri konsep keadilan pemilihan umum menurut UUD 1945." Jurnal Cita Hukum 4.2 (2016): 167-186. DOI: 10.15408/jch.v4i2.4098

Fallon Jr, Richard H. "The rule of law" as a concept in constitutional discourse", Columbia Law Review (1997): 1-56. https://doi.org/10.2307/1123446

J. Mandle, "John Rawls, Justice as Fairness: A Restatement", Journal Utilitas, 14.2, (2002): 265-268. DOI: https://doi.org/10.1017/S0953820800003587

Lindebaum, D., Raftopoulou, E. What Would John Stuart Mill Say? A Utilitarian Perspective on Contemporary Neuroscience Debates in Leadership. J Bus Ethics 144, 813-822 (2017). https://doi.org/10.1007/s10551-014-2247-z

Steven Malby (2017) The rule of law and sustainable development, Commonwealth Law Bulletin, 43:3-4, 521532, DOI: 10.1080/03050718.2017.1436229

Radbruch, Gustav. "Five minutes of legal philosophy (1945)." Oxford Journal of Legal Studies 26.1 (2006): 13-15. https://doi.org/10.1093/ojls/gqi042

Respationo, HM Soerya, and M. Guntur Hamzah. "Putusan Hakim: Menuju Rasionalitas Hukum Refleksif Dalam Penegakan Hukum." Yustisia Jurnal Hukum 2.2 (2013): 101-107.

DOI: https://doi.org/10.20961/yustisia.v2i2.10194 
Stein, Stanley M., and Thomas L. Harper. "Rawls's 'Justice as Fairness': A Moral Basis for Contemporary Planning Theory", Planning Theory Journals, 4.2, (July 2005): 147-172. https://doi.org/10.1177/1473095205054603

Vega, Jesús. "Legal philosophy as practical philosophy." Revus. Journal for Constitutional Theory and Philosophy of Law/Revija za ustavno teorijo in filozofijo prava 34 (2018): 1-24 https://doi.org/10.4000/revus.3859

\section{Newspaper Articles}

Riewanto, A. (2018, September 17). Mahkamah Agung Pembela Caleg Narapidana Korupsi. Opini Media Indonesia.

Yuntho, E. (2018, April 7). Caleg berintegritas. Opini Kompas, pp. 6.

\section{Newspaper Articles on Website}

Farisa, F. C. (2019, FebruarY 28). Pakar: Putusan MA terhadap PKPU Menjauhkan dari Hukum Progresif. Retrieved from https://nasional.kompas.com/read/2018/09/15/11482971/pakar-putusanma-terhadap-pkpu-menjauhkan-dari-hukum-progresif

\section{Website Documents}

Peraturan Komisi Pemilihan Umum Nomor 20 Tahun 2018 tentang Pencalonan Anggota Dewan Perwakilan Rakyat, Dewan Perwakilan Rakyat Daerah Provinsi, dan Dewan Perwakilan Rakyat Daerah Kabupaten/Kota, Berita Negara Republik Indonesia Tahun 2018 Nomor 834. Retrieved from https://jdih.kpu.go.id/data/data_pkpu/FIXED\%20PKPU\%2020\%20THN\% 202018\%20(SINKRONISASI\%20HARMONISASI).pdf

Putusan Mahkamah Agung Nomor 46 P/HUM/2018. Retrieved from https://putusan.mahkamahagung.go.id/putusan/downloadpdf/db34083a 4c17ab94aa322de52eb5a60b/pdf

Undang-Undang Nomor 4 Tahun 2009 Tentang kekuasaan Kehakiman. Retrieved from https://www.dpr.go.id/dokjdih/document/uu/UU_2009_48.pdf

Undang-Undang Nomor 7 Tahun 2017 Tentang Pemilu, Lembaran Negara Republik Indonesia Nomor 182 Tahun 2017, Tambahan Lembaran Negara Nomor 6109. Retrieved from https://referensi.elsam.or.id/wpcontent/uploads/2019/01/UU-Nomor-7-Tahun-2017-UU-Nomor-7-Tahun2017.pdf 